\title{
Health literacy and adherence to drug treatment of type 2 diabetes mellitus
}

Letramento em saúde e adesão ao tratamento medicamentoso do diabetes mellitus tipo 2 Alfabetización en salud y adhesión al tratamiento farmacológico del diabetes mellitus tipo 2

Mariana Rodrigues da Rocha ${ }^{1}$ (ib) Sinderlândia Domingas dos Santos ${ }^{1}$ (iD) Karine Rafaela de Moura ${ }^{(i D}$ Lesliane de Sousa Carvalho ${ }^{1}$ (iD Ionara Holanda de Moura ${ }^{1}$ (i) Ana Roberta Vilarouca da Silva ${ }^{1}$

1. Universidade Federal do Piauí. Teresina, PI. Brasil

2. Universidade Estadual do Piauí. Teresina, PI. Brasil

\section{Abstract}

Objective: To analyze the relationship between health literacy and medication adherence of patients with Type 2 Diabetes Mellitus Method: Quantitative cross-sectional study developed in five Family Health Strategies in the city of Picos, Piauí. Participants comprised 78 users of health services. The "Short Test of Functional Health Literacy in Adults" and the "Treatment Adherence Measurement Test" forms were applied to obtain sociodemographic variables. Descriptive and inferential statistical analysis. Results: Regarding health literacy, $51.3 \%$ of the participants were considered inadequate, and $87.2 \%$ were adherent to the drug treatment. The average of health literacy varied according to the level of medication adherence and sociodemographic variables. Conclusion: Most patients reported to adhere to the medication. Implications for practice: This study identified the health literacy and medication adherence profile of the patients, thus subsidizing the planning of nursing interventions in the attention of diabetes mellitus.

Keywords: Health Literacy; Medication Adherence; Diabetes Mellitus.

\section{RESUMO}

Objetivo: Analisar a relação entre letramento em saúde e adesão ao tratamento medicamentoso de pacientes com diabetes mellitus tipo 2. Método: Estudo quantitativo e transversal desenvolvido em cinco Estratégias de Saúde da Família da cidade de Picos-Piauí. Participaram 78 usuários dos serviços de saúde. Foram utilizados um formulário para obtenção das variáveis sociodemográficas, o "Short Test of Functional Helathy Literacy in Adults", e o "Teste de Medida da Adesão ao Tratamento". Para a análise, utilizou-se estatística descritiva e inferencial. Resultados: Quanto ao letramento em saúde, $51,3 \%$ dos participantes foram classificados como inadequados, e $87,2 \%$ dos participantes foram considerados aderentes ao tratamento medicamentoso. Houve variação da média do letramento em saúde de acordo com o nível de adesão ao tratamento medicamentoso e as variáveis sociodemográficas. Conclusão: Identificou-se relação entre o letramento em saúde e a adesão ao tratamento medicamentoso. Os pacientes, mesmo apresentando, em sua maioria, um letramento em saúde inadequado, referem aderir à terapêutica medicamentosa. Implicações para a prática: O estudo possibilitou identificar o perfil de letramento em saúde e de adesão à terapêutica dos pacientes, subsidiando o planejamento das intervenções de enfermagem na atenção ao diabetes mellitus.

Palavras-chave: Letramento em Saúde; Adesão ao Tratamento Medicamentoso; Diabetes Mellitus.

\section{RESUMEN}

Objetivo: Analizar la relación entre alfabetización en salud y adhesión al tratamiento medicamentoso de pacientes con Diabetes Mellitus Tipo 2. Método: Estudio cuantitativo y transversal desarrollado en cinco Estrategias de Salud de la Familia en Picos, Piauí. Participaron 78 usuarios de los servicios de salud. Se utilizó un formulario con variables sociodemográficas ("Short Test of Functional Healthy Literacy in Adults") y el "Test de Medida de Adhesión al Tratamiento". Análisis estadístico descriptivo e inferencial. Resultados: Para alfabetización en salud, el 51,3\% de los participantes fueron clasificados como inadecuados y $87,2 \%$, adherentes al tratamiento. Hubo variación del promedio de la alfabetización de acuerdo con el nivel de adhesión a la medicación y las variables sociodemográficas. Conclusión: La mayoría confirmó adhesión a la medicación. Implicaciones para la práctica: Se identificó el perfil de alfabetización y adhesión al tratamiento en pacientes, subsidiando la planificación de intervenciones de enfermería en atención al Diabetes Mellitus.

Palabras clave: Alfabetización en Salud; Adhesión al Tratamiento Farmacológico; Diabetes Mellitus.
Corresponding Author:

Ana Roberta Vilarouca da Silva

E-mail: robertavilarouca@yahoo.com.br.

Submitted on $11 / 09 / 2018$

Accepted on 01/10/2019.

DOI: 10.1590/2177-9465-EAN-2018-0325 


\section{INTRODUCTION}

The term literacy refers to the development of the learning process of reading and writing. ${ }^{1}$ Health Literacy $(\mathrm{HL})$ is the person's ability to obtain, process and understand health information and the basic services available that may favor self-care actions. ${ }^{2}$ Over the years, HL has been considered a determinant in the health-disease process. In this direction, patients classified as adequate in $\mathrm{HL}$ are those who have basic reading, writing and numerical skills, which may favor their participation in the care plan, from planning to the evaluation of the results of the proposed therapeutic actions.

The classification of literacy of a person can contribute to know their economic, social, cultural, political and health situation. Thus, over the years the population has been increasingly motivated to seek knowledge and incorporate the new learning methodologies to reach and understand the diverse health information available.

The study points out that low HL can contribute to the appearance and aggravation of several Chronic Non-Communicable Diseases (CNCD), among them Diabetes Mellitus (DM). Its relevance is related to the appearance of chronic complications of DM, that is, nephropathy, retinopathy, peripheral neuropathy, heart disease, among others. ${ }^{3}$

Thus, recognition of the capacity for understanding health information is important so that people receive instructions that can effectively be put into practice for the maintenance of health status. $^{4}$

For effective care related to the pillars of treatment: medication use, physical exercise and food plan following, it is necessary to develop a series of skills and knowledge by the person with DM for successful adherence to treatment.

In this sense, inadequate HL may compromise adherence to treatment of patients with Type 2 Diabetes Mellitus (DM2), irrational drug use, and inadequate self-care practices that trigger acute and chronic complications related to the disease. The impact of low $\mathrm{HL}$ on adherence is so relevant that in the United States the National Patient Information and Education Council has recognized it as one of ten priorities for improving adherence to drug treatment ${ }^{5}$, which refers to the use of prescribed drugs or compliance with other guidelines by at least $80 \%$, considering timing, dose and treatment time. ${ }^{6}$

The Brazilian researches on $\mathrm{HL}$ are recent. The first were performed at the end of the year $2000 .^{7}$ This fact may explain the absence of national publications on the relationship between literacy in health and adherence to drug treatment. Because it is an innovative study, the following research question was elaborated: What is the relation between $\mathrm{HL}$ and adherence to drug treatment in people with T2DM?

The low HL level of people may imply less adherence to health treatments, because for those individuals classified as inadequate, health information and health education actions may not have satisfactory and resolute reach as planned, even when directed by professionals. Thus, investigating the knowledge of $\mathrm{HL}$ in patients with T2DM can offer subsidies for the planning of educational activities, using language accessible to the target public, to improve self-care practices, including adherence to drug treatment, favoring equal, integral and quality care.

In view of the above, the study aimed to analyze the relation between $\mathrm{HL}$ and adherence to drug treatment among people with T2DM.

\section{METHOD}

Quantitative and transversal study developed in Family Health Strategies (FHS) of the city of Picos, Piauí. Currently, the municipality has 36 FHS, 25 of which are located in the urban area and 11 in the rural area. This study was carried out in five FHS in the urban zone, selected due to the higher percentage of people with T2DM registered.

The population of the study consisted of 303 patients, of both sexes, with T2DM, registered and followed up in the five FHS. It was established as inclusion criteria: people enrolled in $\mathrm{BHU}$ and e- Unified Health System, aged over 18 years and medical diagnosis of T2DM for at least two years. The exclusion criteria were: visual deficit, not being able to read and write and not being able to read and write the phrase "CLOSE YOUR EYES" of the Mental State Mini Exam (MSME). These criteria were verified through observation and reporting of patients.

For the sample calculation, the formula with the total population value $(\mathrm{N}=303)$, percentage of $11 \%$ was the reduced variable $(Z=1.96)$, relative sample error $(a=5 \%)$, absolute error $(E=5 \%)$, and the confidence level $(95 \%)^{8}$.

The $11 \%$ of prevalence is based on the overall estimate of adults with diabetes in the year 2015 , estimated at $7.2 \%$ to $11.4 \%$. Thus, the sample was 101 patients with T2DM, but due to difficulties in the complete sample, such as lack of access to the homes, exclusion criteria, lack of collaboration of the health team, and refusal of the patients to participate in the research, the final sample consisted of 78 participants.

For data collection, three instruments were used: a form containing sociodemographic variables; the Short Test of Functional Health Literacy in Adults (S-TOFHLA), in the short version of the Test of Functional Health Literacy in Adults (TOFHLA); and the Measure of Adherence to Treatments (MAT).

S-TOFHLA is an instrument that allows the collection of data to evaluate $\mathrm{HL}$ and is composed of two subtests; one evaluates textual comprehension and the other, mathematical or numerical. The reading ability is evaluated through 36 items and the numerical by four items. The total score is 100 points, with 72 points referring to the reading (weight 2 for each item), and 28 points referring to the numerical (weight 7 for each item), allowing to categorize the respondent in three levels of functional literacy in health: inadequate (0 to 53 points), marginal (54 to 66 points), and adequate (67 to 100 points). The $\mathrm{HL}$ level is reached by the participants through the score of the reading comprehension item added to the numerical. ${ }^{10}$

MAT is a questionnaire used to evaluate adherence to drug treatment, that is, the patient's behavior in relation to the daily use of prescribed drugs. It consists of seven items, on a six-point 
Likert scale, from 1 (always) to 6 (never). The adhesion is determined by the global average of the instrument, that is, the points of each item are added together and divided by the number of items (seven). Treatment adherence is considered when the mean obtained is between five and six points, and "non-adherence" when the mean is less than five points. ${ }^{11-12}$

Data collection took place in the period from February to May 2018, after the identification of people with T2DM in FHS. Next, we sought to know the day of the week in which the consultation of the study participants was scheduled. In the first contact, those who agreed to participate in the survey were informed of the day, time and location. Prior to the application of the form and the questionnaires the objectives and nature of the study were clarified. After the consent of the participant, from the signing of the Informed Consent Term, the reading test was carried out through the application of the "Reading Capacity Assessment Card" of the MSME. The questionnaires were delivered after filling explanation and collected by the researchers.

Data were processed in the IBM Statistical Package for Social Sciences (SPSS) software, version 20.0. For the analysis, were performed the statistical calculations of the sociodemographic quantitative variables, the $\mathrm{HL}$ level and the degree of adherence to drug treatment with regard to absolute and relative frequencies, mean and standard deviation.

In order to evaluate the statistical significance of the items that compose the HL, Person's Correlation Coefficient test was applied. Student's t-tests and one-way ANOVA were used in order to compare the means of the $\mathrm{HL}$ variable with sociodemographic variables and adherence to drug treatment. For all inferential statistical analyses, those with $p<0.05$ were considered as statistically significant.

The study was approved by the Research Ethics Committee of the Federal University of Piauí, according to opinion No.
2,429,535, complying with the norms of Resolution 466/12 of the National Health Council / Ministry of Health.

\section{RESULTS}

Of the $78(100 \%)$ participants, $71.8 \%$ were female, with a mean age of $58.15 \pm 11.44$ years. As for marital status, $66.7 \%$ were married or lived in a stable union. Regarding schooling, an average of $8.81 \pm 5.29$ years of education was identified, of which $82 \%$ attended public schools. Regarding the work situation, $52.6 \%$ of the patients were retired.

With regard to the $\mathrm{HL}$ level of the participants, $51.3 \%$ were classified as inadequate, and only $32.1 \%$ as adequate (Graph 1). On the other hand, $87.2 \%$ of patients were considered to be adherents to drug therapy.

Graph 2 shows that there was a statistically significant correlation between the overall HL score and the reading comprehension and numerical skills items $(p=0.000)$. It was observed that the majority of the participants presented inadequate literacy, and the reading item was the one that most interfered in the result, presenting a stronger correlation $(r=0.956)$.

Table 1 shows that there was variation of the mean of the $\mathrm{HL}$ according to the level of adherence to the drug treatment. Participants who were classified with the appropriate $\mathrm{HL}$ level did not adhere to drug therapy. In contrast, those patients who presented an inadequate $\mathrm{HL}$ level had adherence to the drug treatment $(p=0.025)$.

Table 2 shows that there was an association between the means of the overall $\mathrm{HL}$ score and the sociodemographic variables. Participants in the age group between 30 and 49 years presented marginal or adequate means of HL $(61.80 \pm 18.986)$. Regarding schooling, it was observed that the longer the study, the better the $\mathrm{HL}$ test performance $(73.33 \pm 3.055)$. Patients younger than 10

Graph 1. Level of Health Literacy of diabetic users. Picos - Piauí, 2018. (N=78). Source: Research data. Picos, Piauí, Brazil,2018.

\section{Level of Health Literacy of diabetic users}

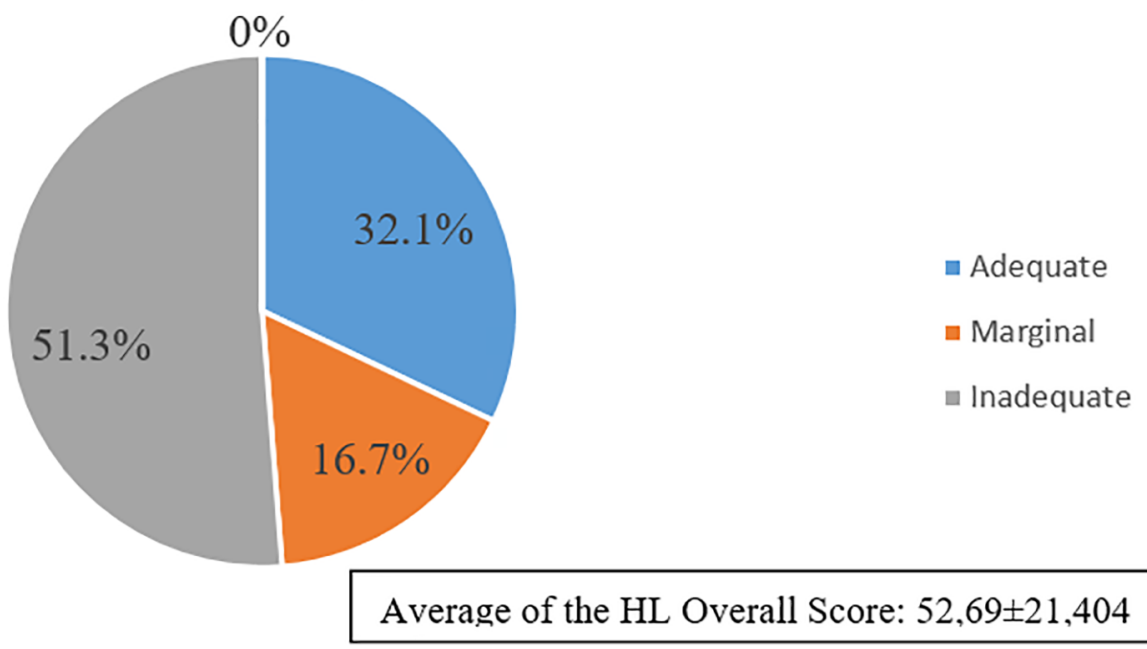


Graph 2. Correlation between the general health literacy score and reading comprehension and numerical skills items, Picos, Piauí, 2018. ( $\mathrm{N}=78$ ). Source: Research data. Picos, Piauí, Brazil, 2018.

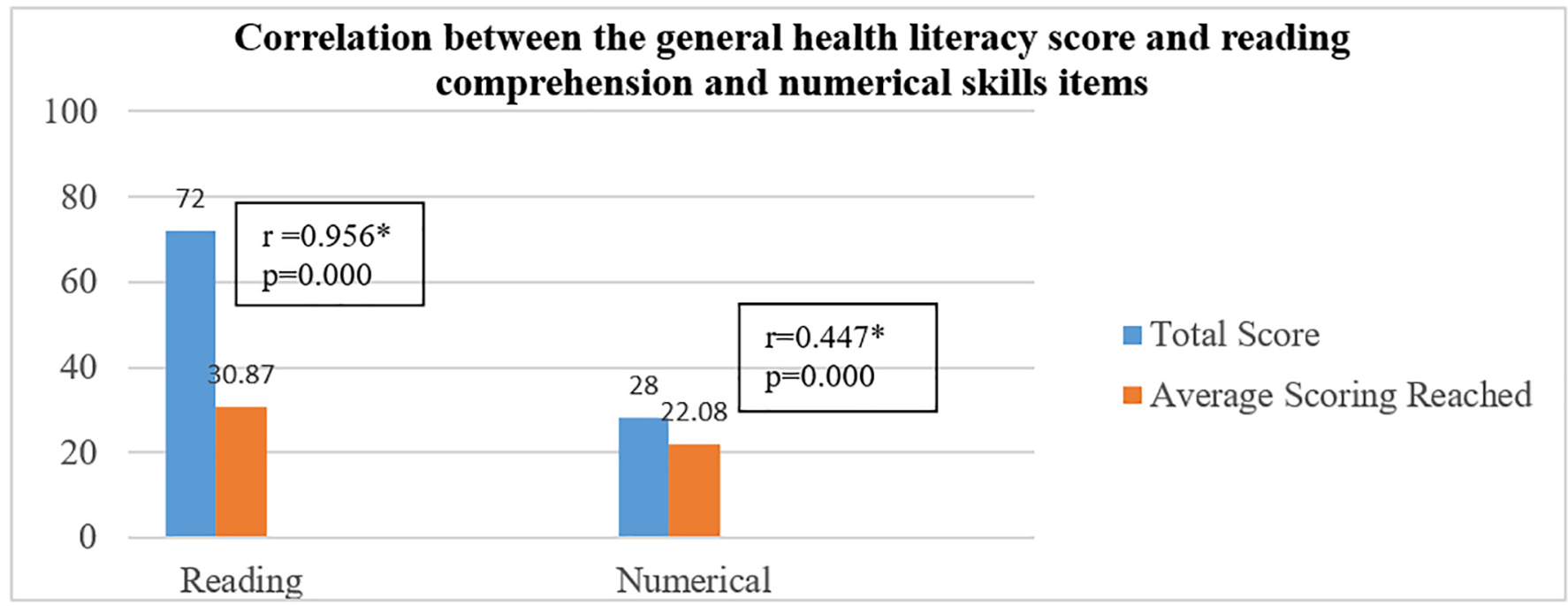

Table 1. Comparison of health literacy with the level of adherence to drug therapy. Picos - PI, 2018. (N=78).

\begin{tabular}{|c|c|c|}
\hline & \multicolumn{2}{|c|}{ Health Literacy } \\
\hline Variable & Average $\pm S D^{*}$ & Value of $p$ \\
\hline \multicolumn{2}{|l|}{ Nível de ADT*** } & $0.025 * *$ \\
\hline Adherence & \multicolumn{2}{|l|}{$50.62 \pm 20.848$} \\
\hline Non Adherence & \multicolumn{2}{|l|}{$66.80 \pm 20.746$} \\
\hline \multicolumn{3}{|c|}{ Source: Research data. Picos, Piauí, Brazil, 2018.} \\
\hline \multicolumn{3}{|l|}{ * SD: Standard Deviation; } \\
\hline \multicolumn{3}{|l|}{ ** Student's t; } \\
\hline
\end{tabular}

Table 2. Association between health literacy and sociodemographic data. Picos, Piauí, Brazil, 2018. (N=78).

\begin{tabular}{lcc}
\hline & \multicolumn{2}{c}{ Health Literacy } \\
\hline Variables & Average \pm SD* & $\begin{array}{c}\text { Value } \\
\text { of p }\end{array}$ \\
\hline $\begin{array}{l}\text { 1. Gender } \\
\text { Female }\end{array}$ & $\mathbf{0 . 9 0 0 ^ { * * }}$ \\
Male & $52.50 \pm 20.816$ \\
2. Age Group & $53.18 \pm 23.337$ & \\
30-49 & $\mathbf{0 . 0 0 2 * * *}$ \\
50-69 & $61.80 \pm 18.986$ & \\
70-89 & $53.00 \pm 20.899$ & \\
3. Marital Status & $33.00 \pm 16.186$ & \\
Married or in a stable union & $56.46 \pm 22.341$ & $\mathbf{0 . 0 2 4 * * *}$ \\
Single & $55.38 \pm 19.574$ & \\
Widowed & $36.54 \pm 12.346$ & \\
Divorced & $51.20 \pm 16.664$ &
\end{tabular}

\begin{tabular}{lcc}
\hline & \multicolumn{2}{c}{ Health Literacy } \\
\hline Variables & Average $\pm S D^{*}$ & $\begin{array}{c}\text { Value } \\
\text { of } \mathbf{p}\end{array}$ \\
\hline 4. Years of study & $\mathbf{0 . 0 0 0 ^ { * * * }}$ \\
$0-9$ years & $44.02 \pm 17.620$ & \\
$10-19$ years & $61.32 \pm 21.983$ & \\
$20-30$ years & $73.33 \pm 3.055$ &
\end{tabular}

5. Type of school attended

$0.003^{* * *}$

Public

$51.66 \pm 20.146$

Private

$35.00 \pm 15.281$

Public and private

$77.57 \pm 20.074$

Others

$43.00 \pm 14.142$

\section{Employment situation}

$0.014 * * *$

Works informally

$54.92 \pm 20.488$

Works formally

$62.31 \pm 21.048$

Does not work

$58.50 \pm 21.564$

Unemployed

$73.75 \pm 16.399$

Retired

$45.61 \pm 19.926$

Source: Research data. Picos, Piauí, Brazil, 2018.

* SD: Standard Deviation;

** Student's t;

*** ANOVA one-way.

years of age have inadequate or marginal $\mathrm{HL}(44.02 \pm 17.620)$.

\section{DISCUSSION}

The present study analyzed the relation between $\mathrm{HL}$ and adherence to drug treatment among 78 people with Type 2 Diabetes Mellitus, of both sexes, with the women composing 
the majority of the sample, being thus in consonance with the National Sample Survey of Households, held in 2015, which presents the Brazilian composition of women corresponding to $51.5 \%$ of the population. ${ }^{13}$

When analyzing the HL level, it was verified that the majority (51.3\%) of the participants presented an inadequate level of $\mathrm{HL}$ performance, with a general average of $52.69 \pm 21.404$ points. This result is in line with other national descriptive studies that sought to analyze the same variable..$^{4,14-15}$

The HL level is reached by the participants by the score of the reading comprehension item added to the numerical skills item. The results obtained show that most of the participants have an inadequate $\mathrm{HL}$ level, and the reading comprehension item is the main influence of this result, since it expresses a stronger correlation $(r=0.956)$ than the numerical skills item $(r=0.477)$.

A study that evaluated the HL of a group of 114 elderly people with T2DM attended at a UHS municipal health unit in the northern region of Brazil, showed a similar result to the present study, since about $52.6 \%$ of the elderly were able to understand and answer the questions related to the numerical comprehension item. ${ }^{14}$

The authors of this study justify this finding, explaining that because the interviewer asked the participant the question about what is on the card, this contributed to improve the level of understanding of the respondents. In the item of textual comprehension, the inadequate result suggests that the applied test presents the written information difficult to understand, requiring a higher level of education, or may contain expressions that make it difficult to understand. ${ }^{14}$

The need to adapt the instrument to the cultural reality of the Brazilian population was also observed during the application of the reading comprehension test, considering that most of the participants questioned the existence of a stomach radiograph, since they relate such examination only to the body's bone structures. Another factor identified was the difficulty of filling in completely the 36 test blanks in a time of only seven minutes. It was observed that the participants with low schooling, in the majority, only completed the items previous to the part related to the day of the X-Ray, contributing, therefore, to the result of inadequacy of the degree of HL.

Regarding adherence to the drug treatment, a satisfactory result was observed, since $87.2 \%$ of the sample followed the treatment. This result is similar to other studies ${ }^{16-17-18}$ that used MAT as an instrument for the analysis of this data.

Thus, it is possible to perceive that even the research showing a good adherence to the drug treatment it is still necessary the elaboration of planning by the health team of the Primary Health Care, so that the coverage of $100 \%$ adherence is achieved. For this, it is essential that the limitations that influence non-adherence to therapy be identified and, from this, implementing of a plan of care compatible with the needs of the users.

The present study also sought to relate the level of $\mathrm{HL}$ to the degree of adherence to the drug treatment and obtained a statistically significant result $(\mathbf{p}=\mathbf{0 . 0 2 5})$, but the initial hypothesis was refuted, since it was verified that the participants even presenting, for the most part, $(51.3 \%)$ an inadequate $\mathrm{HL}$, are adherent to the drug therapy (87.2\%).

Comparing this result with two studies, one national ${ }^{19}$ and another international ${ }^{20}$, there were divergent results, since none showed a statistically significant relation between the two variables, $\mathrm{HL}$ and adherence to drug treatment. These studies ${ }^{19-20}$ seek to justify the findings regarding adherence to drug therapy, attributing the limitations of the studies to the instrument used for the investigation, the MAT, since it uses self-reported information that can be influenced by information and memory bias, and subjects are likely to change responses to the instrument according to what is most appropriate.

By means of the comparison between the averages from the application of the Student's T test, it was verified that the patients who have an adequate $\mathrm{HL}$ do not adhere to the drug therapy. This result can be explained by analyzing the general profile of the participants who presented an adequate $\mathrm{HL}$. The best means were reached by male patients $(53.18 \pm 23.337)$, in the age group of 30 to 49 years $(61.80 \pm 18.986)$, with 20 to 30 years of study $(73.33 \pm 3.055)$.

Considering this information, it is perceived that men are more reckless with the use of medications. The study by Saccomann, Souza Neta and Martins (2015) ${ }^{21}$ showed that men tend to be more careless about taking medications than women, which may be justified by less concern about health. Moreover, this same study ${ }^{21}$ reveals that patients who work out tend to forget to take medication more frequently, and this may be related to the age group, since the age of 30 to 49 corresponds to the stage in which the majority of people are in active employment.

Regarding the level of schooling, White et al (2013) ${ }^{22}$, when investigating 149 patients with DM, showed that patients with limited $\mathrm{HL}$ had greater confidence in professional-oriented information, greater self-care and greater adherence to the nutritional and medication regimen, but patients with higher level of education showed to consider their involvement in medical decision making as a process shared between them. This involves verifying the veracity of the information and seeking options beyond what is given by the health professional.

It is observed that the knowledge of the sociodemographic aspects of the population is of great importance to identify the factors that contribute to determine the results found on adherence to drug treatment and the levels of $\mathrm{HL}$. It allows intervening in the limitations encountered by the users of the health system.

According to Cortez (2015) ${ }^{23}$, the sociodemographic and clinical particularities added to the planning of previous actions can direct the management of care and educational programs by the health team, and especially by nursing.

Thus, aiming at a better understanding of the results found on $\mathrm{HL}$ levels, we investigated the association between mean $\mathrm{HL}$ scores and sociodemographic data. The present study shows that low HL scores are statistically associated with older people, widows, retirees, those with lower levels of schooling and attending private schools.

In the study by Passamai, Sampaio and Lima $(2013)^{24}$, car- 
ried out with 506 users of the Basic Care of the Unified Health System (UHS) in Fortaleza, Ceará, there was agreement with the results of the present study, since the percentages of limited $\mathrm{HL}$ were progressively increased with advancing age, with significant difference between the age groups $(p<0.001 /$ Chi-Square Test). In addition, $93.6 \%$ of the population that had 1 to 3 years of schooling had a limited HL.

These results are confirmed in an integrative literature review ${ }^{25}$ in which the authors showed that in the analysis of the quantitative articles low $\mathrm{HL}$ is related to low schooling, older age, low income and to be male.

Thus, low $\mathrm{HL}$ in patients with T2DM could make impossible proper self-care and managing of the quality of treatment, thus directly harming the understanding and acquisition of health practices, as well as increasing and developing complications and disabilities.

This study had some limitations, such as the difficulty of finding literate people to read and respond to the questionnaires. Concerning the $\mathrm{HL}$ instrument, it was observed the incomprehension of the same, because the participants were unaware of the procedure described in the questions. Many associated the questions with their reality, not understanding that it was a simulation, and could not answer all items in the estimated time. Based on this, it is necessary to carry out studies that seek to adapt the $\mathrm{HL}$ instrument to the cultural reality of the research participants.

\section{CONCLUSION}

The studied population presented a high prevalence of inadequacy in $\mathrm{HL}$, followed by an adequate adherence to drug treatment. The comparison between these two variables obtained a statistically significant result. It was observed that the patients, even presenting an inadequate $\mathrm{HL}$, adhere to the drug therapy. In contrast, participants with an appropriate HL are not adherent to drug treatment.

This finding was justified by the analysis of sociodemographic characteristics. Studies indicate that patients with low schooling tend to trust and adhere adequately to the guidelines of health professionals. On the other hand, individuals with adequate $\mathrm{HL}$, who were mostly males of less age and with more years of schooling, tend to be careless, forgetful and negligent about treatment.

Thus, the importance of this work is highlighted, as it explores a new and poorly evaluated subject among patients with T2DM. It is of fundamental importance also for health professionals, especially nurses, since it makes it possible to know the difficulties present in the patients and to promote health practices that fit the reality of each individual, thus guaranteeing greater involvement between the professional and the patient, providing adequate treatment and, consequently, greater empowerment of the user with T2DM in their health-disease process.

\section{REFERENCES}

1. Soares M. Letramento: um tema em três gêneros. Belo Horizonte: Autêntica; 2006.

2. Institute of Medicine (IOM). Health Literacy: A Prescription to End Confusion. Washington, DC: National Academies Press; 2004. 367 p Available from: www.nap.edu

3. Sociedade Brasileira de Diabetes. Diretrizes da Sociedade Brasileira de Diabetes (2017-2018). São Paulo: Editora Clannad; 2017.

4. Sampaio HAC, Carioca AAF, Sabry MOD, Santos PM, Coelho MAM Passamai MPB. Letramento em saúde de diabéticos tipo 2: fatores associados e controle glicêmico. Ciênc Saúde Coletiva [Internet] 2015 Mar;20(3):865-74. Available from: http://www.scielo.br/scielo. php?script=sci_arttext\&pid=S1413-81232015000300865. DOI: 10.1590/1413-81232015203.12392014

5. Martins NFF, Abreu DPG, Silva BT, Semedo DSRC, Pelzer MT, lenczak FS. Functional health literacy and adherence to the medication in older adults: integrative review. Rev Bras Enferm [Internet]. $2017 \mathrm{Jul} /$ Aug;70(4):868-74. DOI: http://dx.doi.org/10.1590/0034-7167-20160625

6. Leite SN, Vasconcellos MPC. Adesão à terapêutica medicamentosa: elementos para a discussão de conceitos e pressupostos adotados na literatura. Ciênc Saúde Coletiva [Internet]. 2003;8(3):775-82. Available from: http://www.scielo.br/pdf/csc/v8n3/17457.pdf. DOI: 10.1590/ S1413-81232003000300011

7. Maragno CAD, Luiz PPV. Letramento em saúde e adesão ao tratamento medicamentoso: uma revisão da literatura. Rev Inic Cient [Internet]. 2016;14(1):1-4. Available from: http://periodicos.unesc.net/ iniciacaocientifica/article/view/2672

8. Miot HA. Tamanho da amostra em estudos clínicos e experimentais. J Vasc Bras [Internet]. 2011; 10(4):275-8. Available from: http:// www.scielo.br/pdf/jvb/v10n4/v10n4a01. DOI: 10.1590/S167754492011000400001

9. International Diabetes Federation (IDF). Diabetes Atlas [Internet]. 7a ed. Brussels: International Diabetes Federation; 2015. Available from: https://www.idf.org/e-library/epidemiology-research/diabetes-atlas/13 diabetes-atlas-seventh-edition.html

10. Baker DW, Willians MV, Parker RM, Gazmararian JA, Nurss J. Development of a brief test to measure functional health literacy. Patient Educ Couns [Internet]. 1999 Sep;38(1):33-42. Available from: https://www.ncbi.nlm.nih.gov/pubmed/14528569. DOI: S07383991(98)00116-5

11. Faria HTG, Santos MA, Arrelias CCA, Rodrigues FFL, Gonela FT, Teixeira CRS, et al. Adesão ao tratamento em diabetes mellitus em unidades da Estratégia Saúde da Família. Rev Esc Enferm USP [Internet]. 2014;48(2):257-63. Available from: http://www.revistas.usp.br/ reeusp/article/view/84086. DOI: 10.1590/S0080623420140000200009

12. Boas LCGV, Foss-Freitas MC, Pace AE. Adesão de pessoas com diabetes mellitus tipo 2 ao tratamento medicamentoso. Rev Bras Enferm [Internet]. 2014;67(2):268-73. Available from: http://www. scielo.br/scielo.php?pid=S0034-71672014000200268\&script=sci_ abstract\&tlng=pt. DOI: 10.5935/0034-7167.20140036

13. Ministério do Planejamento, Desenvolvimento e Gestão (BR). Instituto Brasileiro de Geografia e Estatística (IBGE). Síntese de indicadores sociais: uma análise das condições de vida da população brasileira 2016 / IBGE, Coordenação de População e Indicadores Sociais, Rio de Janeiro: IBGE; 2016.

14. Santos MIPO, Portella MR. Condições do letramento funcional em saúde de um grupo de idosos diabéticos. Rev Bras Enferm [Internet] 2016;69(1):156-64. Available from: http://www.scielo.br/scielo. php?pid=S0034-71672016000100156\&script=sci_abstract\&tlng=pt DOI: S0034-71672016000100156

15. Borges FM. Fatores Associados ao Letramento em Saúde de Adultos Hipertensos [monografia]. Picos: Universidade Federal do Piauí; 2017. 
16. Martins AC. Adesão à Terapêutica Medicamentosa em doentes com Diabetes Mellitus Tipo 2: um estudo no ACES Almada e Seixal. [dissertação\#\&093;. Lisboa: Universidade Nova de Lisboa; 2014. Available from: https://run.unl.pt/handle/10362/14648

17. Penaforte KL, Araújo ST, Fernandes VO, Barbosa IV, Cestari VRF, Júnior Montenegro RM. Associação entre polifarmácia e adesão ao tratamento farmacológico em pacientes com diabetes. Rev Rene [Internet]. 2017 Sep-Oct;18(5):631-8. Available from: http://www.periodicos. ufc.br/rene/article/viewFile/30827/71490. DOI: 10.15253/21756783.2017000500010

18. Souza JD, Baptista MHB, Gomides DS, Pace AE. Adesão ao cuidado em diabetes mellitus nos três níveis de atenção à saúde. Esc Anna Nery [Internet]. 2017;21(4):e20170045. Available from: http://www.scielo.br/ pdf/ean/v21n4/pt_1414-8145-ean-2177-9465-EAN-2017-0045.pdf. DOI: 10.1590/2177-9465-EAN-2017-0045

19. Seignemartin BA. Letramento em saúde e adesão ao tratamento medicamentoso de pacientes diabéticos tipo $2 \mathrm{em}$ um hospital terciário [dissertação\#\&093;. Campinas: Universidade Estadual de Campinas; 2018. Available from: http://repositorio.unicamp.br/bitstream/ REPOSIP/331281/1/Seignemartin_BeatrizAraujo_M.pdf

20. Bains SS, Egede LE. Associations between health literacy, diabetes knowledge, self-care behaviors, and glycemic control in a low income population with type 2 diabetes. Diabetes Technol Ther [Internet]. 2011 Mar;13(3):335-41. https://www.ncbi.nlm.nih.gov/pubmed/21299402. DOI: 10.1089/dia.2010.0160
21. Saccomann ICR, Souza Neta JG, Martins BF. Fatores associados à adesão ao tratamento medicamentoso em hipertensos de uma Unidade de Saúde da Família. Rev Fac Ciênc Med (Sorocaba) [Internet] 2015;17(1):21-6. Available from: http://revistas.pucsp.br/index.php/ RFCMS/article/view/20861/pdf

22. White RO, Osborn CY, Gebretsaddik T, Kripalani S, Rothman RL. Health literacy, physician trust, and diabetes-related self-care activities in Hispanics with limited resources. J Health Care Poor Underserved [Internet]. 2013 Nov;24(4):1756-68. Available from: https://www.ncbi. nlm.nih.gov/pubmed/24185168. DOI: 10.1353/hpu.2013.0177

23. Cortez DN, Reis IA, Souza DAS, Macedo MML, Torres HC. Complicações e o tempo de diagnóstico do diabetes mellitus na atenção primária Acta Paul Enferm [Internet]. 2015;28(3):250-5. Available from: http:// www.scielo.br/pdf/ape/v28n3/1982-0194-ape-28-03-0250.pdf. DOI: 10.1590/1982-0194201500042

24. Passamai MPB, Sampaio HAC, Lima JWO. Letramento funcional em saúde de adultos no contexto do Sistema Único de Saúde. Fortaleza: EdUECE; 2013. Available from: http://www.uece.br/eduece/index.php/ downloads/doc_details/2041-letramento-funcional-em-saude-deadultos-no-contexto-do-sistema-unico-de-saude

25. Rocha PC, Lemos SMA. Aspectos conceituais e fatores associados ao letramento funcional em saúde: revisão de literatura. Rev CEFAC [Internet]. 2016;18(1):214-25. Available from: http://www.scielo.br/pdf/ rcefac/v18n1/1982-0216-rcefac-18-01-00214.pdf. DOI: 10.1590/1982021620161819615 